\title{
Implikasi Kesesuaian Penempatan dan Komitmen Organisasi pada Kinerja Karyawan di Kota Pontianak (Studi Kasus pada Karyawan Rumah Sakit Swasta di Kota Pontianak)
}

\author{
Pasifikus Maisirata \\ E-mail:pmaisirata@yahoo.com \\ Sekolah Tinggi Ilmu Ekonomi Widya Dharma, Jalan H.O.S Cokroaminoto No. 445, Pontianak, \\ Kalimantan Barat, 78111, Indonesia
}

\begin{abstract}
Abstrak
Pada masa sekarang, perkembangan dunia usaha mengalami kemajuan disemua bidang terutama di bidang ekonomi, hal ini berkaitan erat dengan berbagai upaya yang dilakukan pemerintah di antaranya adalah perbaikan di bidang ekonomi. Saat ini banyak ditemukan usaha-usaha yang dilakukan untuk membantu dan mempermudah dalam memenuhi kebutuhan dan keperluan sehari-hari. Untuk memenuhi kebutuhan tersebut banyak dibuka berbagai perusahaan. Penelitian ini bertujuan untuk mengetahui pengaruh kesesuaian penempatan dan komitmen organisasional terhadap kinerja karyawan. Hasil pengujian koefisien determinasi $\left(\mathrm{R}^{2}\right)$ dari variabel independen mampu menjelaskan pengaruhnya terhadap kompetensi karyawan adalah sebesar 26,80 persen, sedangkan sisanya 73,20 persen dijelaskan oleh faktor-faktor lain yang tidak digunakan dalam penelitian ini. Hasil pengujian parsial ( $\mathrm{t}$ test) menunjukkan nilai signifikansi komitmen organisasional $0,000<0,05$, sehingga komitmen organisasional berpengaruh signifikan terhadap kinerja. Dari rata-rata tanggapan responden dapat diketahui bahwa karyawan memiliki kesesuaian penempatan yang baik dan tingkat kinerja berdasarkan kerjasama yang tinggi. Hasil uji $t$ menunjukkan bahwa kesesuaian penempatan memiliki signifikan sebesar $0,000<0,05$. Hal ini berarti kesesuaian penempatan berpengaruh secara signifikan terhadap kinerja karyawan karena nilai signifikansi lebih kecil dari nilai pembanding yaitu 0,05 . Hasil pengujian koefisien determinasi $\left(\mathrm{R}^{2}\right)$ menunjukkan pengaruh variable kesesuaian penempatan terhadap kinerja karyawan sebesar 28,00 persen, sisanya sebesar 72,00 persen dipengaruhi oleh variabel lain diluar kesesuaian penempatan yang tidak di uji
\end{abstract}

Kata kunci: Kinerja, Kepuasan Dalam Bekerja dan Balanced Scorecard

\begin{abstract}
In the present, the development of the business world has progressed in all fields, especially in the economic field, this is closely related to various efforts made by the government, including improvements in the economic field. At present many efforts are being made to help and facilitate the fulfillment of daily needs and needs. To meet these needs many companies opened a lot. This study aims to determine the effect of the suitability of placement and organizational commitment on employee performance. The test results of the coefficient of determination (R2) of the independent variables are able to explain the effect on employee competencies of 26.80 percent, while the remaining 73.20 percent is explained by other factors not used in this study. The partial test results ( $t$ test) show the significance value of organizational commitment 0,000 <0,05, so that organizational commitment has a significant effect on performance. From the responses of the average respondents, it can be seen that employees have a good fit and performance level based on high collaboration. The results of the t test show that the match placement has a significance of 0,000 <0,05. This means that the match placement has a significant effect on employee performance because the significance value is lower than the comparison value of 0.05. The
\end{abstract}


results of the coefficient of determination testing (R2) indicate the effect of variable placement suitability on employee performance by 28.00 percent, while the remaining 72.00 percent is influenced by other variables beyond the suitability of placements that are not tested

Keywords: Performance, Satisfaction In Work and Balanced Scorecard

\section{A. Pendahuluan}

Sumber daya manusia merupakan faktor yang penting dalam sebuah perusahan. Dikatakan penting karena keberadaannya sangat menentukan keberhasilan dantercapainya sasaran yang diinginkan. Tujuan-tujuan yang hendak dicapai oleh perusahaan yang satu dengan yang lainnya mungkin berbeda-beda, namun tujuan utama perusahaan adalah mandapatkan laba semaksimal mungkin, maka untuk mendapatkan laba dibutuhkan sumber daya manusia yang berkualitas.

Kesesuaian penempatan mempunyai peran penting dalam kesuksesan karyawan, karena aktivitas ini dapat menunjukkan kemampuan untuk dapatberadaptasi,berkembang, dan bertahandalam menghadapi setiap ancaman ditengah persaingan.Penempatan merupakan penugasan kembali seorang pekerja pada suatu pekerjaan atau jabatan baru. Penempatan merupakan proses pemberian tugas dan pekerjaan tenaga kerja yang lulus seleksi untuk dilaksanakan sesuai dengan ruang lingkup yang telah ditetapkan.Kesesuaian penempatan juga merupakanposisi pekerjaan yang tepat. Ketepatan menempatkan karyawan merupakan faktor penting dalam usaha membangkitkan semangat kerja karyawan.

Pada dasarnya penilaian kinerja karyawan merupakan hal yang diinginkan baik dari pemilik kerja maupun para pekerja. Kinerja juga merupakan perilaku nyata yang ditampilkan setiap orang sebagai prestasi kerja yang dihasilkan oleh karyawan sesuai dengan perannya dalam perusahaan. Penilaian karyawan juga merupakan proses yang dilakukan organisasi untuk menilai keberasilan dalam melaksanakan tugasnya. Kinerja merupakan suatu fungsi dari motivasi dan kemampuan menyelesaikan pekerjaannya. Kinerja karyawan merupakan kesediaan dalam meningkatkan kemampuan tertentu. Kinerja merupakan keterampilan seseorang untukmengerjakan sesuatu yang jelas tentang apa yang dikerjakan dan bagaimana mengerjakannya.

Menurut Luthans (2006: 224) "komitmen organisasional adalah keinginan kuat untuk tetap bertahan sebagai anggota organisasi, keinginan untuk berusaha keras sesuai keinginan 
organisasi, dan keyakinan tertentu demi mencapai tujuan organisasi. Karena itu peran sumber daya manusia, khususnya jajaran manajemen dari lini dasar sampai lini puncak harus mampu berperan sebagai penggerak untuk mewujudkan misi dan visi organisasi. Komitmen organisasional seseorang terhadap organisasi atau perusahaan menjadi isu yang sangat penting dalam dunia kerja.Berdasarkan penelitian sebelumnya yang dilakukan oleh Gunthar Riady (2013) dengan judul "Pengaruh Penempatan Kerja Terhadap Kinerja Pegawai" menunjukan bahwa terdapat pengaruh yang signifikan terhadap kinerja pegawai

Selain itu, hasil penelitian sebelumnya yang dilakukan oleh Yovita Aldilanigsari (2014) dengan judul "Pengaruh Kesesuaian Penempatan Terhadap Kinerja Karyawan" memiliki pengaruh yang signifikan terhadap kinerja karyawan.

Penelitian ini juga dilakukan oleh Maisaroh (2007) dengan judul "Pengaruh Penempatan Terhadap Kinerja Karyawan" hasil penelitiannya juga menunjukan bahwa variabel independent memiliki pengaruh yang signifikan terhadap variabel dependen

Menurut Ghorbanpour, Dehnavi, Heyrani (2014) yaitu komitmen organisasi memiliki pengaruh positif yang signifikan pada kinerja karyawan, komitmen normatif meninggalkan efek paling kuat pada rata-rata kinerja, dibandingkan dengan komitmen afektif dan komitmen berkelanjutan.

Berdasarkan uraian uraian sebelumnya, maka penulis merasa perlu dilakukan suatu penelitian terhadap Impikasi Kesesuaian Penempatan Dan Komitmen Organisasi Pada Kinerja Karyawan Di Kota Pontianak (Studi Kasus Pada Karyawan Rumah Sakit Swasta di Kota Pontianak)

\section{B. Literatur Review}

\section{Penempatan Karyawan}

Penempatan adalah tindak lanjut dari seleksi yaitu menempatkan calon karyawan yang diterima pada jabatan/pekerjaan yang membutuhkannya dan sekaligustanggung jawab pada pekerjaannya. Jika fungsi ini tidak dilaksanakan dengan baik maka dengan sendirinya akan berakibat buruk terhadap pencapaian tujuan organisasi. Menurut Mathis dan Jackson (2012:262); berpendapat bahwa penempatan adalahpemberian kerja yang sesuaipadakeahlian yang dumiliki setiap karyawan pekeryawan. MenurutSiswanto 
(2008:162);penempatan karyawan adalah proses pemberian tugas dan pekerjaan kepada karyawan yang telah diterima dan dilatih. sedangkanSchuler dan Jackson (2007:276); mendifinisikanpenempatan karyawan berkaitan dengan pencocokan seseorang dengan jabatan yang akan dipegangnya berdasarkan pada jabatan dengan pengetahuan, keterampilan, kemampuan dan kepribadian yang baik.

Menurut Sugiyono (2008: 165) kriteria yang harus dipenuhi dalam pelaksanaan penempatan karyawan antara lain:

a. Pengetahuan

Merupakan suatu kesatuan informasi terorganisir yang biasanya terdiri dari sebuah fakta atau prosedur yang diterapkan secara langsung terhadap kinerja.

b. Kemampuan

Menunjukan kesanggupan, kecakapan seseorang dalam melakukan tugas dan pekerjaan yang dibebankan kepadanya.

c. Sikap

Sikap merupakan pernyataan evaluatif yang baik dan menguntungkan, hal ini menyangkut obyek, orang atau peristiwa dimana sikap dapat mencerminkan bagaimana seseorang merasakan sesuatu.

d. Keterampilan

Keterampilann merupakan kecekatan dalam mengerjakan tugas dan kewajibannya.

e. Pengalaman

Merupakan suatu pengaruh tanggapnya seseorang terhadap orang lain, objek atau situasi yang berhubungan dengannya.

Pemilihan proses penempatan sangat penting dilaksanakan, agar pelaksanaannya efektif dalam mendukung tercapainya tujuan perusahaan. Pemimpin yang cakap dapat menerapkan proses yang sesuai dan dengan pelaksanaan tugas-tugasnya. Sebelum mengadakan penempatan karyawan, perlu melihat proses yang harus ditempuh dalam penempatan karyawan. MenurutSulistiyani dan Rosidah (2009:155);menentukan kebutuhan dalam melakukan sumber daya manusia dan anggaran pelaksanaan agar dapat 
tercapai tujuan perusahaan. Adapun proses-proses yang harus ditempuh dalam hal ini, menurut Sulistiyani dan Rosidah (2009:155); adalahmenentukan kebutuhan-kebutuhan sumber daya manusia, mengupayakan persetujuan anggaran untuk mengadakan atau mengisi jabatan. Sedangkan Menurut Siswanto (2008:162);penempatan karyawan adalah proses pemberian tugas dan pekerjaan kepada tenaga kerja yang lulus seleksi untuk dilaksanakan sesuai ruang lingkup yang telah ditentukan. Pemilihan proses penempatan sangat penting dilaksanakan, agar pelaksanaannya efektif dalam mendukung tercapainya tujuan perusahaan. Sebelum mengadakan penempatan karyawan, perlu melihat proses yang harus ditempuh dalam penempatan karyawan agar sesuai dengan kretria yang dari suatu perusahaan. MenurutSunyoto(2012: 122);menyatakan, penempatan merupakan proses atau pengisian jabatan atau penugasan kembali karyawanpada tugas atau jabatan baru atau jabatan yang berbeda.Sebagian besar keputusan penempatan diambiloleh manajer lini, dalam hal ini atasan langsung kepada karyawan yang bersangkutan.

Kinerja karyawan merupakan usaha yang mendorong karyawan untuk mampu berkerja dengan baik dan memdapatkan hasil yang maksimal bagi organisasi. MenurutSedarmayanti(2011:260);mengemukakan bahwa kinerja merupakan hasil kerja seorang pekerja, sebuah proses suatu organisasi secara keseluruhan, dimana hasil kerja tersebut harus dapat dibuktikan. Sedangkan Mangkunegara (2009:67);mengemukakan bahwa kinerja adalah hasil kerja yang dicapai oleh seorang karyawan dalam melaksanakan tugasnya sesuai dengan tanggung jawab yang diberikan kepadanya. MenurutBangun (2012:230);peningkatkan kerja merupakanhal yang diingikan baik dari pihak pemberi maupun pekerja.

Menurut Wirawan (2009:80);menjelaskan pengembangan dimensi dan indikator instrumen evaluasi kinerja yaitu:

a. Kuantitas

Kuantitas hasil kerja merupakan jumlah yang harus diselesaikan. Pengukuran ini melibatkan perhitungan keluaran dari proses atau pelaksanaan kegiatan.

b. Kualitas

Kualitas hasil kerja merupakan mutu yang dihasilkan. Pengukuran ini berkaitan dengan bentuk keluaran dan mencerminkan seberapa baik penyelesaiannya. 
c. Ketepatan waktu

Ketepatan waktu merupakan sesuai tidaknya waktu yang direncanakan. Pengukuran ini menentukan ketepatan waktu dalam kegiatan. Perilaku kerja yang terdiri dari disiplin kerja, dan inisiatif.

d. Kedisplinan

Kedisplinan kerja adalah keinginan dan kesadaran untuk mentaati peraturan dan norma pada perusahaan.

e. Inisiatif

Inisiatif adalah keinginan melakukan pekerjaan diluar tugasnya.

Menurut Mangkunegara (2009 :67);hasil kerja karyawan yang dilihat dari kuantitas dan kualitas dalam melaksanakan tugas dan tangung jawabnya. Sedangkan Hasibuan (2009:160); hasil kerja seseorang secara cekatan, dan kesempatan yang diberikan kepada karyawan. Dari beberapa pendapat tersebut dapat artikan bahwa kinerja karyawan merupakan suatu hasil yang dicapai seseorang dalam melaksanakan pekerjaannya baik secara kualitas maupun secara kuantitas dalam melaksanakan tugas-tugas yang diberikan berdasarkan kesesuaian pengetahuan, kesesuaian ketrampilan dan kesesuaian sikap demi tercapainya tujuan perusahaan.

Oleh karena itu dapat diartikan bahwa kinerja sumber daya manusia adalah suatu prestasi kerja baik kualitas maupun kuantitas yang dicapai pada priode waktu dalam melaksanakan tugas dengan tanggung jawab yang diberikan kepadanya. Prestasi yang didapatkan oleh karyawan juga bisa dikatakan penilaian baik manajer maupun karyawan memproleh umpan balik dan mereka dapat saling memperbaiki kesalahan dalam pekerjaan.

\section{Komitmen Organisasional}

Komitmen organisasional merupakan ukuran kesediaan karyawan bertahan dengan sebuah perusahaan di waktu yang akan datang. Komitmen kerap kali mencerminkan kepercayaan karyawan terhadap misi dan tujuan organisasi, kesediaan melakukan usaha dalam menyelesaikan pekerjaan, serta hasrat terus bekerja di sana.

Menurut Kaswan (2012: 293) komitmen organisasional biasanya lebih kuat di antara karyawan lama, mereka yang telah mengalami kesuksesan pribadi dalam oraganisasi, dan mereka yang bekerja di dalam tim yang berkomitmen. 
Menurut Mayer dan Allen (2007), yang dikutip oleh Kaswan (2012: 293-294):

Komitmen organisasi terdiri atas tiga dimensi:

a. Komitmen afektif

Menunjukkan kuatnya keinginan emosional karyawan untuk beradaptasi dengan nilai-nilai yang ada agar tujuan dan keinginan untuk tetap di organisasi dapat terwujud. Komitmen afektif timbul pada diri seorang karyawan dikarenakan adanya: karakteristik individu, karakteristik struktur organisasi, signifikansi tugas, berbagai keahlian, umpan balik dari pemimpin, dan keterlibatan dalam manajemen. Umur dan lama masa kerja di organisasi sangat berhubungan positif dengan komitmen afektif. Karyawan yang memiliki komitmen afektif akan cenderung untuk tetap dalam satu organisasi karena mereka mempercayai sepenuhnya misi yang dijalankan oleh organisasi.

b. Komitmen berkelanjutan

Merupakan komitmen yang didasari atas kekhawatiran seseorang terhadap kehilangan sesuatu yang telah diperoleh selama ini dalam organisasi, seperti: gaji, fasilitas, dan yang lainnya. Hal-hal yang menyebabkan adanya komitmen kelanjutan, antara lain adalah umur, jabatan, dan berbagai fasilitas serta berbagai tunjangan yang diperoleh. Komitmen ini akan menurun jika terjadi pengurangan terhadap berbagai fasilitas dan kesejahteraan yang diperoleh karyawan.

c. Komitmen normatif

Menunjukkan tanggung jawab moral karyawan untuk tetap tinggal dalam organisasi. Penyebab timbulnya komitmen ini adalah tuntutan sosial yang merupakan hasil pengalaman seseorang dalam berinteraksi dengan sesama atau munculnya kepatuhan yang permanen terhadap seorang panutan atau pemilik organisasi dikarenakan balas jasa, respek sosial, budaya dan agama.

Berdasarkan kajian literatur yang dibahas, maka disusun kerangka pemikiran sebagai berikut: 


\section{GAMBAR 1}

\section{KERANGKA PEMIKIRAN}

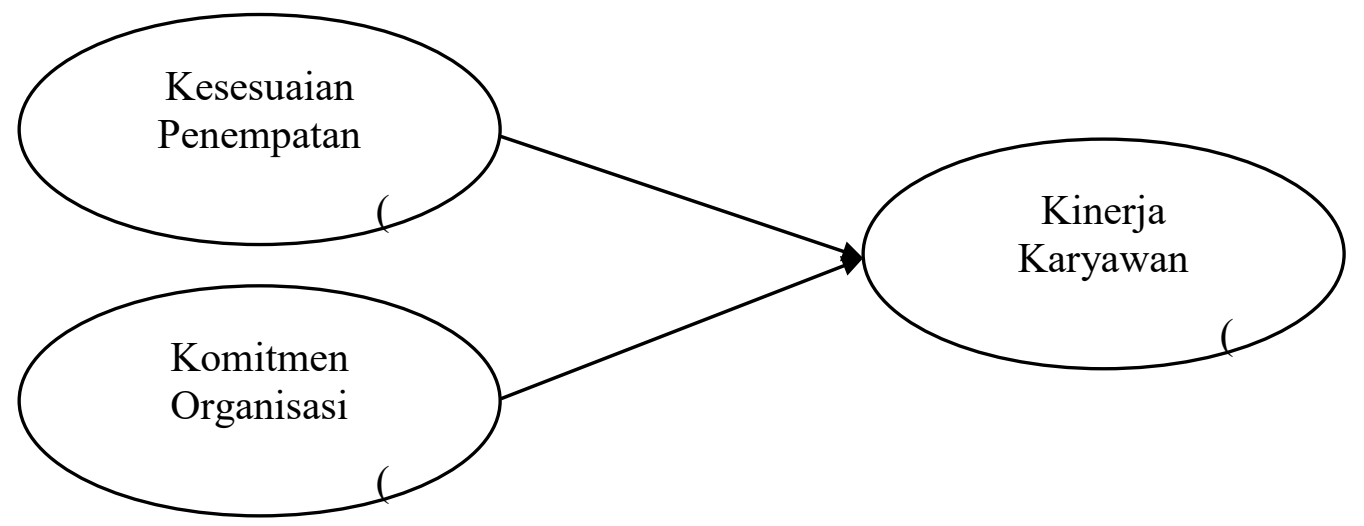

Berdasarkan tinjauan literatur yang telah dipaparkan, maka disusun hipotesis yang digunakan dalam penelitian ini. Hipotesis merupakan penilaian sementara terhadap hubungan antara dua variabel atau lebih. Menurut Sugiyono (2016:134-135); hipotesis juga dapat dinyatakan sebagai jawaban yang masih perlu di uji kebenaran nya.

Ho: Tidak terdapat pengaruh yang signifikan antara variabel kesesuaianpenempatan dan komitmen organisasi hadap kinerja Karyawan.

$\mathrm{H}_{1}$ : Terdapat pengaruh yang signifikan antara variabel kesesuaian penempatan terhadap kinerja Karyawan.

$\mathrm{H}_{2}$ : Terdapat pengaruh yang signifikan antara variabel komitmen organisasi terhadap kinerja Karyawan.

\section{Metode Penelitian}

Bentuk penelitian yang digunakan dalam penulisan ini adalah metode analisis kualitatif. Penelitian ini untuk mengukur pengaruh kesesuaian penempatan terhadap kinerja karyawan. Teknik pengumpulan data yang digunakan adalah kuesioner dan studi dokumenter. Sampel dalam penelitian ini berjumlah 100 orang karyawan swasta yang bekerja di kota Pontianak. Populasi dalam penelitian ini para karyawan yang bekerja pada Rumah Sakit swasta di kota Pontianak yang berjumlah 852 orang sedangkan sampel dalam penelitian ini diambil dengan menggunakan metode purposive sampling dan diperoleh responden sebanyak 90 responden. Dalam penelitian ini data dianalisis dengan bantuan skala Likert dan program Statistical Package for the Social Sciences (SPSS). Adapun variabel-variabel yang diteliti antara lain 
Kesesuaian Penempatan, Komitmen Organisasi dan Kinerja Karyawan. Adapun definisi operasional variabel pada penelitian ini dapat dilihat pada Tabel 1 berikut ini:

TABEL 1

DEFINISI OPERASIONAL VARIABEL

\begin{tabular}{|c|c|c|}
\hline Variabel & Indikator & Kuesioner \\
\hline \multirow{10}{*}{$\begin{array}{l}\text { Penempatan } \\
\left(\mathrm{X}_{1}\right)\end{array}$} & \multirow[t]{2}{*}{$\begin{array}{l}\text { Kesesuaian } \\
\text { Pendidikan }\end{array}$} & $\begin{array}{l}\text { Posisi yang dimiliki sudah sesuai dengan pendidikan } \\
\text { terakhir. }\end{array}$ \\
\hline & & $\begin{array}{l}\text { Bisa mengikuti peletihan sesuai dengan aturan dan } \\
\text { ketentuan yang berlaku. }\end{array}$ \\
\hline & \multirow[t]{2}{*}{$\begin{array}{l}\text { Kesesuaian } \\
\text { Pengalaman }\end{array}$} & $\begin{array}{l}\text { Jabatan yang saya miliki sesuai dengan pengalaman } \\
\text { kerja sebelumnya. }\end{array}$ \\
\hline & & $\begin{array}{l}\text { Rasa percaya diri yang besar dalam melakukan } \\
\text { pekerjaan yang pernah dilakukan sebelumnya. }\end{array}$ \\
\hline & \multirow[t]{2}{*}{$\begin{array}{l}\text { Kesesuaian } \\
\text { Keterampilan }\end{array}$} & $\begin{array}{l}\text { Tidak mengalami kesulitan dalam menyelesaikan tugas } \\
\text { pekerjaan. }\end{array}$ \\
\hline & & $\begin{array}{l}\text { Bisa mengerjakan pekerjaan secara cekatan sesuai } \\
\text { keterampilan yang saya miliki. }\end{array}$ \\
\hline & \multirow[t]{2}{*}{$\begin{array}{l}\text { Kesesuaian } \\
\text { Pengetahuan }\end{array}$} & $\begin{array}{l}\text { Dapat menguasai pekerjaan dan tanggung jawab yang } \\
\text { diberikan. }\end{array}$ \\
\hline & & $\begin{array}{l}\text { Dapatmenyelsaikan masalah dalam setiap pekerjaan } \\
\text { yang diberikan kepadanya. }\end{array}$ \\
\hline & \multirow[t]{2}{*}{$\begin{array}{l}\text { Kesesuaian } \\
\text { Kemampuan }\end{array}$} & $\begin{array}{l}\text { Memiliki potensi dalam melakukan pekerjan yang } \\
\text { diberikan kepadanya. }\end{array}$ \\
\hline & & $\begin{array}{l}\text { Lingkungan kerja sesuai dengan karakteristik yang saya } \\
\text { miliki. }\end{array}$ \\
\hline \multirow{3}{*}{$\begin{array}{l}\text { Komitmen } \\
\text { organisasional } \\
\left(\mathrm{X}_{2}\right)\end{array}$} & $\begin{array}{l}\text { Komitmen } \\
\text { Afektif }\end{array}$ & $\begin{array}{l}\text { Memiliki rasa yang mendalam secara pribadi untuk } \\
\text { bertahan pada perusahaan } \\
\text { Rasa saling memiliki yang kuat dengan organisasi } \\
\text { Ingin menjadi anggota organisasi yang setia }\end{array}$ \\
\hline & $\begin{array}{l}\text { Komitmen } \\
\text { Berkelanjutan }\end{array}$ & $\begin{array}{l}\text { Merasa terganggu bila berhenti bekerja } \\
\text { Merasa sulit mencari pekerjaan baru } \\
\text { Mengharapkan mendapatkan keuntungan apabila } \\
\text { bertahan }\end{array}$ \\
\hline & $\begin{array}{l}\text { Komitmen } \\
\text { Normatif }\end{array}$ & $\begin{array}{l}\text { Kesetiaan yang harus diberikan karena pengaruh orang } \\
\text { lain } \\
\text { Kewajiban untuk memberikan kontribusi terbaik kepada } \\
\text { perusahaan } \\
\text { Memiliki kewajiban untuk setia terhadap perusahaan }\end{array}$ \\
\hline \multirow{2}{*}{$\begin{array}{l}\text { Kinerja } \\
\text { Karyawan (Y) }\end{array}$} & \multirow[t]{2}{*}{ Kualitas } & $\begin{array}{l}\text { Karyawan berhati-hati dalam bekerja untuk mengurangi } \\
\text { kesalahan dalam bekerja. }\end{array}$ \\
\hline & & $\begin{array}{l}\text { Karyawan menyelesaikan pekerjaan sesuai standar yang } \\
\text { telah ditetapkan. }\end{array}$ \\
\hline
\end{tabular}




\begin{tabular}{|c|c|c|}
\hline Variabel & Indikator & Kuesioner \\
\hline & \multirow[t]{2}{*}{ Kuantitas } & $\begin{array}{l}\text { Saya menyelesaikan pekerjaan sesuai dengan telah } \\
\text { ditetapkan. }\end{array}$ \\
\hline & & $\begin{array}{l}\text { Hasil kerja yang saya kerjakan sudah baik dari } \\
\text { sebelumnya. }\end{array}$ \\
\hline & \multirow[t]{2}{*}{$\begin{array}{l}\text { Ketepatan } \\
\text { waktu }\end{array}$} & $\begin{array}{l}\text { Saya menyelesaikan pekerjaan sesuai dengan waktu } \\
\text { yang ditentukan. }\end{array}$ \\
\hline & & $\begin{array}{l}\text { Saya menggunkan waktu dengan sebaik mungkin dalam } \\
\text { bekerja. }\end{array}$ \\
\hline & \multirow[t]{2}{*}{ Kemandirian } & $\begin{array}{l}\text { Saya bisa mengerjakan pekerjaan tanpa bantuan orang } \\
\text { lain. }\end{array}$ \\
\hline & & $\begin{array}{l}\text { Bisa menyelesaikan setiap pekerjaan yang diberikan } \\
\text { kepada saya. }\end{array}$ \\
\hline & \multirow[t]{2}{*}{ Kerja sama } & $\begin{array}{l}\text { Saya selalu terbuka terhadap pendapat orang yang ada } \\
\text { dalam lingkungan kerja. }\end{array}$ \\
\hline & & $\begin{array}{l}\text { Bisa saling menghargai dan menghormati pendapat } \\
\text { rekan kerja. }\end{array}$ \\
\hline
\end{tabular}

Sumber: Hasil kajian literatur, 2018

\section{Hasil Penelitian dan Pembahasan}

1. Hasil Penelitian

\section{a. Karakteristik Responden}

1) Pengelompokan responden berdasarkan jenis kelamin

Pengelompokan responden berdasarkan jenis kelamin, bertujuan untuk mengetahui berapa banyak laki-laki, dan berapa banyak perempuan, pengelompokan ini dapat dilihat pada Tabel 2 sebagai berikut:

TABEL 2

PENGELOMPOKAN RESPONDEN BERDASARKAN JENIS KELAMIN

\begin{tabular}{|c|c|c|}
\hline Jenis Kelamin & Jumlah & Persentase \\
\hline Laki-laki & 25 & 27,78 \\
\hline Perempuan & 65 & 72,22 \\
\hline Jumlah & 90 & 100,00 \\
\hline
\end{tabular}

Sumber: Data Olahan, 2018 
2) Pengelompokan responden berdasarkan usia

Pengelompokan ini bertujuan untuk mengetahuijumlah responden berdasarkan rentang usia.Pengelompokan ini dapat dilihat pada Tabel 3 berikut ini:

TABEL 3

\section{PENGELOMPOKANRESPONDEN BERDASARKAN USIA}

\begin{tabular}{|l|l|l|}
\hline $\begin{array}{l}\text { Umur } \\
\text { (tahun) }\end{array}$ & Responden & Persentase \\
\hline$\leq 20$ & 0 & 0,00 \\
\hline $21-30$ & 34 & 37,78 \\
\hline $31-40$ & 17 & 18,89 \\
\hline $41-50$ & 30 & 33,33 \\
\hline$\geq 51$ & 9 & 10,00 \\
\hline Jumlah & 90 & 100,00 \\
\hline
\end{tabular}

Sumber: Data Olahan, 2018

TABEL 4

REKAPITULASI TANGGAPAN RESPONDEN

\begin{tabular}{|l|l|l|}
\hline No & Kuesioner & $\begin{array}{l}\text { Rata- } \\
\text { rata }\end{array}$ \\
\hline Kesesuaian Pendidikan & 4,30 \\
\hline 1 & Posisi saya sudah sesuai dengan pendidikan terakhir & 4,32 \\
\hline 2 & Bisa mengikuti peletihan sesuai dengan aturan dan ketentuan yang berlaku & $\mathbf{4 , 3 1}$ \\
\hline Rata-rata kesesuaian pendidikan & \\
\hline Kesesuaian Pengalaman & 4,11 \\
\hline 1 & Jabatan yang saya miliki sesuai dengan pengalaman kerja sebelumnya & 4,03 \\
\hline 2 & $\begin{array}{l}\text { Rasa percaya diri yang besar dalam melakukan pekerjaan yang pernah } \\
\text { dilakukan sebelumnya. }\end{array}$ & \\
\hline Rata-rata kesesuaian pengalaman & $\mathbf{4 , 0 7}$ \\
\hline Kesesuaian Keterampilan & 3,97 \\
\hline 1 & Tidak mengalami kesulitan dalam menyelesaikan tugas pekerjaan. & \\
\hline 2 & $\begin{array}{l}\text { Bisa mengerjakan pekerjaan secara cekatan sesuai keterampilan yang saya } \\
\text { miliki }\end{array}$ & 4,10 \\
\hline Rata-rata kesesuaian keterampilan & $\mathbf{4 , 0 4}$ \\
\hline Kesesuaian Pengetahuan & 4,14 \\
\hline 1 & Dapat menguasai pekerjaan dan tanggung jawab yang diberikan. & \\
\hline 2 & $\begin{array}{l}\text { Dapat menyelsaikan masalah dalam setiap pekerjaan yang diberikan } \\
\text { kepadanya. }\end{array}$ & 4,01 \\
\hline Rata-rata kesesuaian pengetahuan & $\mathbf{4 , 0 8}$ \\
\hline Kesesuaian Kemampuan & 3,93 \\
\hline 1 & Memiliki potensi dalam melakukan pekerjan yang diberikan kepadanya. \\
\hline 2 & Lingkungan kerja sesuai dengan karakteristik yang saya miliki. & 3,78 \\
\hline
\end{tabular}




\begin{tabular}{|c|c|c|}
\hline No & Kuesioner & $\begin{array}{l}\text { Rata- } \\
\text { rata }\end{array}$ \\
\hline \multicolumn{2}{|c|}{ Rata-rata kesesuaian kemampuan } & 3,86 \\
\hline \multicolumn{2}{|c|}{ Kualitas } & \\
\hline 1 & $\begin{array}{l}\text { Karyawan berhati-hati dalam bekerja untuk meminimalisir kesalahan dalam } \\
\text { hasil kerja. }\end{array}$ & 4,04 \\
\hline 2 & Karyawan mampu bekerja sesuai dengan standar kerja yang telah ditentukan & 4,18 \\
\hline \multicolumn{2}{|r|}{ Rata-rata Kualitas } & 4,11 \\
\hline \multicolumn{2}{|c|}{ Kuantitas } & \\
\hline 1 & Saya menyelesaikan pekerjaan sesuai dengan yang telah ditetapkan. & 3,93 \\
\hline 2 & Hasil kerja yang saya kerjakan sudah baik dari sebelumnya. & 3,99 \\
\hline \multicolumn{2}{|r|}{ Rata-rata Kuantitas } & 3,96 \\
\hline \multicolumn{2}{|c|}{ Ketepatan Waktu } & \\
\hline 1 & Saya menyelesaikan pekerjaan sesuai dengan waktu yang ditentukan. & 3,96 \\
\hline 2 & Saya menggunkan waktu dengan sebaik mungkin dalam bekerja. & 4,10 \\
\hline \multicolumn{2}{|c|}{ Rata-rata Ketepatan waktu } & 4,03 \\
\hline \multicolumn{2}{|c|}{ Kemandirian } & \\
\hline 1 & Saya bisa mengerjakan pekerjaan tanpa bantuan orang lain. & 3,47 \\
\hline 2 & Bisa menyelesaikan setiap pekerjaan yang diberikan kepada saya. & 3,86 \\
\hline \multicolumn{2}{|c|}{ Rata-rata Kemandirian } & 3,67 \\
\hline \multicolumn{2}{|c|}{ Kerja sama } & \\
\hline 1 & $\begin{array}{l}\text { Saya selalu terbuka terhadap pendapat orang yang ada dalam lingkungan } \\
\text { kerja. }\end{array}$ & 4,16 \\
\hline 2 & bisa menghargai pendapat rekan kerja. & 4,20 \\
\hline \multicolumn{2}{|r|}{ Rata-rata Kerja sama } & 4,18 \\
\hline \multicolumn{3}{|c|}{ Komitmen Afektif } \\
\hline 1 & Masalah yang terjadi di perusahaan menjadi permasalahan saya juga & 4,04 \\
\hline 2 & Menjadi bagian keluarga pada perusahaan & 4,32 \\
\hline \multirow[t]{2}{*}{3} & Bahagia bisa menghabiskan sisa karir di perusahaan & 4,13 \\
\hline & Rata-rata Komitmen Afektif & 4,16 \\
\hline \multicolumn{3}{|c|}{ Komitmen Berkelanjutan } \\
\hline 1 & Kemungkinan tidak mendapatkan kesempatan kerja yang sama & 3,64 \\
\hline 2 & Merasa rugi untuk keluar perusahaan & 3,78 \\
\hline & Ingin bertahan di perusahaan & 3,89 \\
\hline \multicolumn{2}{|c|}{ Rata-rata Komitmen Berkelanjutan } & 3,77 \\
\hline \multicolumn{3}{|c|}{ Komitmen Normatif } \\
\hline 1 & Perusahaan banyak memberikan jasa & 4,19 \\
\hline 2 & Perusahaan layak mendapat kesetiaan & 4,00 \\
\hline 3 & Seorang karyawan harus setia terhadap perusahaan & 4,05 \\
\hline
\end{tabular}

Sumber: Data Olahan, 2018 
b. Uji Asumsi Klasik

TABEL 5

UJI NORMALITAS

METODE ONE SAMPLE KOLMOGOROV-SMIRNOV

One-Sample Kolmogorov-Smirnov Test

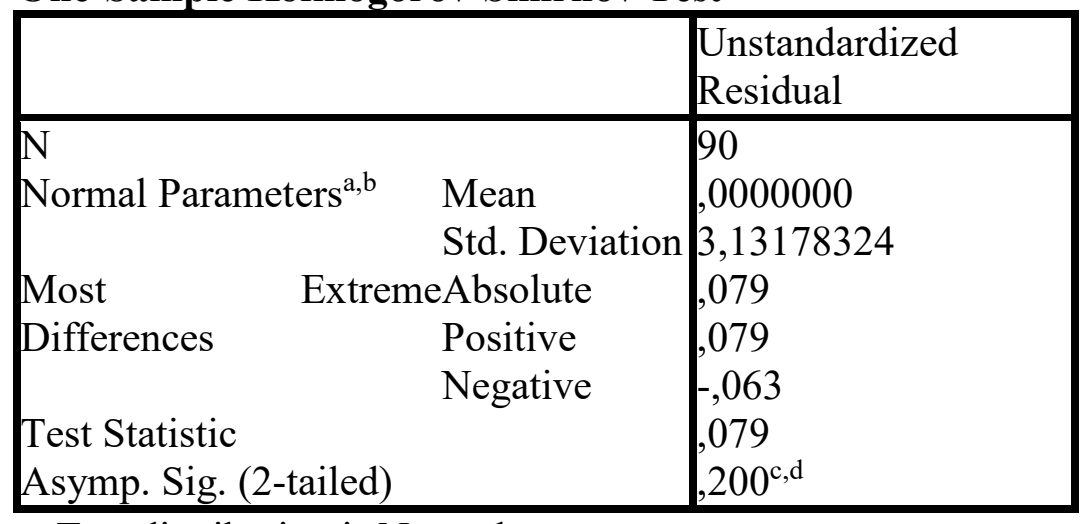

a. Test distribution is Normal.

b. Calculated from data.

Sumber: Data olahan Program SPSS Versi, 2018

Dari Tabel 5 tersebut dapat diketahui nilai Asymp. Sig. (2-tailed) lebih besar dari 0,05 atau 0,200>0,05, maka dapat diketahui bahwa data dari uji normalitas terdistribusi dengan normal dan pengujian data dapat dilakukan ke tingkat selanjutnya.

c. Uji Koefisien Determinasi $\left(\mathrm{R}^{2}\right)$

TABEL 6

UJI KOEFISIEN DETERMINASI $\left(\mathbf{R}^{2}\right)$

Model Summary ${ }^{b}$

\begin{tabular}{|l|l|l|l|l|}
\hline Model & $\mathrm{R}$ & R Square & $\begin{array}{l}\text { Adjusted } \\
\text { Square }\end{array}$ & $\begin{array}{l}\mathrm{R} \\
\text { Std. Error of the } \\
\text { Estimate }\end{array}$ \\
\hline 1 &, $530^{\mathrm{a}}$ &, 281 &, 273 & 3,150 \\
\hline
\end{tabular}

a. Predictors: (Constant), kesesuaian penempatan

Sumber: Data olahan Program SPSS, 2018

Pada Tabel 6 tersebut, nilai R square adalah 0,281 atau sebesar 28,10 persen, yang artinya bahwa variabel kesesuaian penempatan mempengaruhi kinerja karyawan sebesar 28,10 persen sedangkan 72,90 persen dipengaruhi faktor lain. 
d. Uji Analisis Koefisien Determinasi $\left(\mathrm{R}^{2}\right)$

Uji ini untuk mengetahui seberapa besar persentasi pengaruh variabel independen terhadap variabel dependen. Berikut perhitungan uji analisis koefisien determinasi pada Tabel 3.49:

TABEL 7

\section{UJI ANALISIS KOEFISIEN DETERMINASI $\left(\mathbf{R}^{2}\right)$}

\section{Model Summary}

\begin{tabular}{|l|l|l|l|l|}
\hline Model & R & R Square & Adjusted R Square & Std. Error of the Estimate \\
\hline 1 &, $518^{\mathrm{a}}$ &, 268 &, 250 & 4,796 \\
\hline
\end{tabular}

Predictors: (Constant), Organzational Citizenship Behavior, Komitmen

Organisasional

Dependent Variable: Kinerja

Sumber: output SPSS, 2018

Berdasarkan Tabel $7 \mathrm{di}$ atas, nilai koefisien determinasi $\left(\mathrm{R}^{2}\right)$ adalah sebesar 0,268 atau sama dengan 26,80 persen. Angka tersebut menunjukkan bahwa komitmen organisaional memiliki pengaruh terhadap kinerja sebesar 26,80 persen. Sedangkan sisanya $(100 \%-26,80 \%=73,20 \%)$ dipengaruhi oleh faktor lain. Analisis regresi linear sederhana

Hasil analisis regresi linear sederhana dapat dilihat pada Tabel 8 sebagai berikut:

\section{TABEL 8}

ANALISIS REGRESI LINEAR SEDERHANA

\section{Coefficients $^{\mathrm{a}}$}

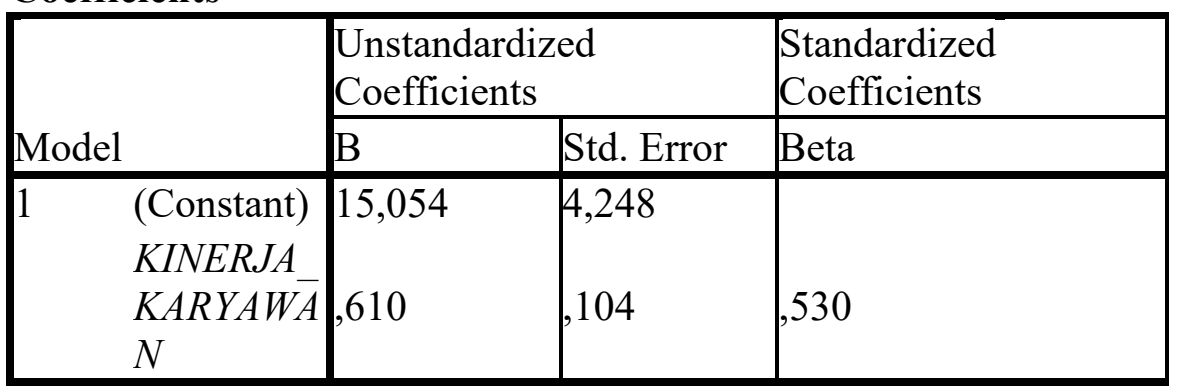

a. Dependent KINERJA KARYAWAN

Sumber: Data olahan Program SPSS Versi, 2018

Dari Tabel 8 tersebut dapat diperoleh persamaan model regresi sebagai berikut: 


$$
\begin{aligned}
& Y=a+b x \\
& Y=15,054+0,610 X_{1}
\end{aligned}
$$

Intepretasi dari regresi tersebut dapat dijelaskan sebagai berikut:

1) Konstanta memiliki nilai sebesar 15,054 , artinya jika tidak ada variabel indenpenden lain, maka nilai kinerja karyawan adalah sebesar 15,054.

2) Koefisien regresi variabel kesesuaian penempatan memiliki nilai sebesar 0,610. Artinya jika nilai variabel kesesuaian penempatan mengalami kenaikan satu-satuan, maka kinerja karyawan akan mengalami kenaikan sebesar 0,610. Koefisien memiliki hubungan yang positif artinya hubungan kedua variabel memiliki hubungan yang positif.

\section{TABEL 9}

\section{UJI ANALISIS REGRESI LINEAR BERGANDA}

\begin{tabular}{|c|c|c|c|}
\hline \multirow[b]{2}{*}{ Model } & \multicolumn{2}{|c|}{ Unstandardized Coefficients } & Standardized Coefficients \\
\hline & $\mathrm{B}$ & Std. Error & Beta \\
\hline$($ Constant $)$ & 21,752 & 6,292 & \\
\hline Komitmen Organisasional &, 643 &, 130 &, 484 \\
\hline
\end{tabular}

\section{Coefficients $^{\mathrm{a}}$}

Dependent Variable: RES2

Sumber: output SPSS, 2018

Berdasarkan Tabel 9 di atas, maka diperoleh model regresi sebagai berikut:

$$
Y^{\prime}=21,752+0,643 X
$$

Model persamaan regresi tersebut dapat dijelaskan sebagai berikut:

1) Nilai koefisien regresi komitmen organisasional $\left(b_{1}\right)$ memiliki nilai sebesar 0,643 . Koefisien bernilai positif artinya terjadi hubungan yang positif antara komitmen organisasional $\left(\mathrm{X}_{1}\right)$ dengan kinerja karyawan $(\mathrm{Y})$, semakin tinggi nilai komitmen organisasional $\left(\mathrm{X}_{1}\right)$ maka semakin tinggi nilai kinerja karyawan $(\mathrm{Y})$ dan sebaliknya. 
TABEL 10

UJI t

\section{Coefficients $^{\mathrm{a}}$}

\begin{tabular}{|c|c|c|c|c|c|}
\hline \multirow[b]{2}{*}{ Model } & \multicolumn{2}{|c|}{ Unstandardized Coefficients } & \multirow{2}{*}{\begin{tabular}{|l} 
Standardized \\
Coefficients \\
Beta
\end{tabular}} & \multirow[b]{2}{*}{$\mathrm{T}$} & \multirow[b]{2}{*}{ Sig. } \\
\hline & $\mathrm{B}$ & Std. Error & & & \\
\hline (Constant) & 15,054 & 4,248 & & 3,544 & 4,001 \\
\hline $\begin{array}{l}\text { Kinerja_ } \\
\text { karyawan }\end{array}$ &, 610 &, 104 &, 530 & 5,861 & 1,000 \\
\hline
\end{tabular}

a. Dependent Variable: KINERJA_KARYAWAN

Sumber: Data olahan Program SPSS Versi, 2018

Berdasarkan Tabel 3.32 tersebut, diketahui nilaithitungvariabel kesesuaian penempatan adalah sebesar $0,000<0,05$,sehingga variabel kesesuaian penempatan berpengaruh secara signifikan terhadap variabel kinerja karyawan.

\section{Hasil Pengujian Hipotesis}

Hal ini dibuktikan dengan nilai signifikansi kesesuaian penempatansebesar 0,000<0,05 dan nilai signifikan. Sehingga hipotesis yang diajukan penulis yaitu ada pengaruh antara variabelkesesuaian penempatan terhadap kinerja karyawan, hal ini menunjukan bawah hipotesis yang dilakukan dapat diterima. Hasil pengujian data serta pembahasan pada tabel uji $t$ menyimpulkan bahwa komitmen organisasional berpengaruh signifikan terhadap kinerja karyawan. Hal ini dibuktikan dengan nilai signifikansi komitmen organisasional sebesar 0,000 lebih kecil dari nilai signifikansi yang menjadi pembanding yaitu 0,05. Hipotesis yang diajukan penulis yaitu komitmen organisasional signifikansi terhadap kinerja karyawan diterima.

\section{E. Penutup}

1. Kesimpulan

Hasil analisis data dan pembahasan tentang pengaruh Kesesuaian Penempatan terhadap kinerja karyawan pada karyawan swasta di kota Pontianak, maka dapat diambil kesimpulan sebagai berikut: 
a. Dari rata-rata tanggapan responden dapat diketahui bahwa karyawan memiliki kesesuaian penempatan yang baik dan tingkat kinerja berdasarkan kerjasama yang tinggi.

b. Hasil uji $t$ menunjukkan bahwa kesesuaian penempatan memiliki signifikan sebesar $0,000<0,05$. Hal ini berarti kesesuaian penempatan berpengaruh secara signifikan terhadap kinerja karyawan karena nilai signifikansi lebih kecil dari nilai pembanding yaitu 0,05 .

c. Komitmen organisasional berpengaruh positif dan signifikan terhadap kinerja karyawan pada Rumah Sakit Santo Antonius Pontianak.

2. Saran-saran

Berdasarkan hasil penelitian dan kesimpulan di atas, maka berikut saran-saran yang dapat diberikan penulis yaitu:

a. Kinerja karyawan yang ditunjukkan dan dipekerjakan pihak Rumah Sakit swasta di kota Pontianak sudah baik, dan diharapkan kepada pihak rumah sakit untuk mempertahankan dan memingkatkan kemampuan dari setiap karyawan dalam melakukan tugasnya masing-masing.

b. Untuk penelitian selanjutnya diharapkan agar penelitian ini dapat digunakan sebagai salah satu sumber data dalam melakukan penelitian lebih lanjut berdasarkan faktor lainnya, diluar faktor kesesuaian penempatan dan kinerja karyawan.

\section{Daftar Referensi}

Arikunto, Suharsimi. (2006). Prosedur Penelitian Suatu Pendekatan Praktik. Jakarta: PT Asdi Mahasatya.

Bangun, Wilson. (2012). Manajemen Sumber Daya Manusia:Jakarta. PT Gelora Aksara Pratama.

Barthos, Basir. (2012). Manajemen Sumber Daya Manusia: suatu pendekatan makro. - Ed. 1, Cet. 9. Jakarta: Bumi Aksara.

Darajat, Luthfah Nurfaizah Dan Rosyidah. (2012). "Hubungan Budaya Organisasi Dengan Komitmen Orgnisasi Perawat Bagian Rawat Inap Kelas II Dan Kelas III Rumah Sakit 
Umum PKU Muhammadiyah Yogyakarta”. Jurnal KES MAS Vol.6 No.2 (Juni). ISSN: 1920-0575.

Elfliani, Destria, Amin Mustofa Dan Ahmad Mardalis. (2015). "Pengaruh Motivasi, Budaya Organisasi Dan Komitmen Organisasi Terhadap Kinerja Perawat Rumah Sakit Umum Dr. Moewardi Surakarta”. Jurnal Ekonomi Manajemen Sumber Daya Vol.17 No.1 (Juni). Hal 13.

Ghozali, Imam. (2011). Aplikasi Analisis Multivariate Dengan Program IBM SPSS 19. Semarang: Badan Penerbit Universitas Diponegoro.

Handoko, T. H. (2008). Manajemen Personalia dan Sumber Daya Manusia. Penerbit BPFE UGM. Yogyakarta.

Hasibuan, Malayu. (2009). Manajemen Sumber Daya Manusia. Penerbit Bumi Aksara. Jakarta. . (2014). Manajemen Sumber Daya manusia. Bandung: Remaja Rosdakarya.

Kasmir. (2017). Manajemen Sumber Daya Manusia: Teori Dan Praktik. Depok: Rajawali Pers.

Kaswan. (2012). Manajemen Sumber Daya Manusia: Untuk Keunggulan Bersaing Organisasi.Edisi Pertama. Yogyakarta: Graha Ilham.

Luthans, Fred. (2006). Prilaku Organisasi. Ed.10. Yogyakarta: PT. Andi.

Mangkunegara, A. P. (2009). Manajemen Sumber Daya Manusia Perusahaan. Penerbit PT. Remaja Rosdakarya. Bandung.

Mathis, R. L dan J. H Jackson. (2012). Manajemen Sumber Daya Manusia. Penerbit Salemba Empat. Jakarta.

Nawawi, H. (2008). Manajemen Sumber Daya Manusia Untuk Bisnis yang Kompetitif. Penerbit Gadjah Mada Univesity Press. Yogyakarta.

Novelia, Mery, Bambang Swasto Dan Ika Ruhana. (2016). "Pengaruh Komitmen Dan Organizational Citizenhsip Behavior(OCB) Tehadap Kinerja (Studi Pada Tenaga 
Keperawatan Rumah Sakit Umum Daerah Dr. Sorgiri Lamongan).” Jurnal Administrasi Bisnis (JAB) Vol. 38 No.2 (September). Hal 77.

Prawirosentono. (2009). Manajemen Produktivitas. Penerbit PT. Bumi Angkasa. Jakarta.

Priansa, Juni Donni. (2016). Perencanaanaan Pengembangan SDM. Bandung: Alfabeta.

Priyatno, Duwi. (2016). SPSS 22 Pengelolaan Data Praktis. Yogyakarta: Andi.

Putri, Yumma Dalin Dan Hamidah Nayati Utami. (2017). "Pengaruh Organizational Citizenhsip Behavior (OCB) Terhadap Kinerja (Studi Pada Tenaga Perawat Ruang Rawat Inap Rumah Sakit Baptis Batu).” Jurnal Administrasi Bisnis (JAB) Vol.46 No.1 (Mei).

Rivai, V. (2009). Manajemen Sumber Daya Manusia Untuk Perusahaan dari Teori dan Praktik. Penerbit PT. Raja Grafindo Persada. Jakarta.

Robbins, Stephen.P. Perilaku Organisasi. Ed.10. Jakarta: PT. Jaya Cemerlang.

Schuler dan Jackson. (2007). Manajemen Sumber Daya Manusia. Penerbit PT. Raja Grafindo Persada. Jakarta.

Sedarmayanti. (2011). Manajemen Sumber Daya Manusia, Reformasi Birokrasi, dan Manajemen Pegawai Negeri Sipil. Penerbit PT Refika Aditama. Bandung.

Siswanto. (2008). Manajemen Personalia. Penerbit PT Erlangga. Jakarta.

Sugiyono. (2015). Statistik Nonparametris Untuk Penelitian. Bandung: Alfabeta.

. (2017). Metode Penelitian Kuantitatif Kualitatif dan R\&B. Penerbit Alfabeta. Bandung, 2017. 